DOI: $10.31861 /$ pytlit2018.98.317

\author{
УДК: 821.111-312.1 Мер.09
}

\title{
POLYVALENCE OF THE CAVE PARADIGM: IRIS MURDOCH'S RECEPTION
}

\author{
Aliona Matiychak \\ orcid.org/0000-0002-8190-0427 \\ amatiychak@gmail.com \\ Department of Foreign Languages for Humanitarian Colleges \\ Yuriy Fedkovych Chernivtsi National University \\ 2 Kotsiubynskiy Street, 58012, Chernivtsi, Ukraine
}

\begin{abstract}
The article analyzes the literary and philosophical aspects of the Cave paradigm both in the context of Iris Murdoch's fiction and her philosophical essays. The purpose of the article is to study the specifics of the Cave paradigm embodiment in the genrelogic structure of Murdoch's philosophical novel. The multiple-aspect approach to the issue is proposed. In addition to the gnoseologic and gender aspects much attention is paid to the ethic-aesthetic structure component of Murdoch's literary texts. Investigation of this paradigm in such view makes it possible to realize the resources of the author's style, emphasizing the connection between the author's ethics and the aesthetics of her fiction. In this case the proto-text is the famous Plato's myth about the Cave and the meta-text to reveal Murdoch's reception of this myth and interpretations in her novels are her own writings: "The Sovereignty of Good over other Concepts", "The Fire and the Sun: Why Plato Banished the Artists", "Concepts of Unity. Art". As for cognition, likewise Plato, Murdoch regards the idea of Good has a limit, and it is vaguely recognizable, but having recognized it, we come to the conclusion that it is precisely the cause of all that is the true and beautiful. Developing the metaphor of the sun, as the understanding of the Good, Murdoch finds it extremely rich. Unlike her theoretical and philosophical writings, in her novels Murdoch ironically plays with the Plato's myth. She considers the Cave as a "magic space", "theatre space", "sacred space", "place of initiation" or a "place of illusions". The author's interpretation of the Cave paradigm is unique, worthy of a true philosopher. It is revealed by means of the material (topos) and spiritual (logos) factors correlation.Overall, this is no longer a real topos, but the consciousness of her characters as such, with all its mazes, shadows, dark corners, unconscious queer illusions.
\end{abstract}

(C) Матійчак A., 2018 
Key words: Iris Murdoch, reception, the Cave paradigm, the Good as a moral category; gnoseologic, gender, ethic and aesthetic aspects.

To create a holistic image of the world in fiction, Iris Murdoch repeatedly made full use of symbolic forms, capable of immersing individual phenomena into the inception state. The writer was interested in the entire spectrum of philosophical and psychological problems of man in the modern world. As for the genre of her novels, almost all of them are characterized by features of a philosophical parable, full of polyvalent symbols. A peculiar stimulus and inexhaustible source of her philosophical reflections and fiction (26 novels) was Plato's 'Theory of Forms' [gr. eidos - image, form], in particular the ways of its metaphorical and symbolic embodiment [13, p. 388-389].

From the standpoint of analytical psychology, the way a person experiences the perception of eternal symbols is largely due to deep unconscious structures, archetypes. As an example we turn to the Cave paradigm. The ancient image of the cave gave rise to a large number of significant culturological interpretations (arche-text). The lack of discreteness in the cultural tradition, according to S. Averintsev, is manifested in the fact that already known images constantly "enter among themselves in kaleidoscopic-unique combinations" [5, p. 60]. So, since the ancient days cosmos was depicted as a cave (the treatise "On the Cave of the Nymphs" of Neoplatonic philosopher Porphyry). The same applies to the use of the image of the cave, which symbolizes the universe (the cult of Mithras), as well as the biblical notion of "irmament" (the heavens) that covers the earth with the dome (the interior of the Eastern Christian Church symbolizes the totality of the universe) [5, p. 59] and so on. In addition, K. G. Jung says that cave symbolizes the main attribute of the maternal archetype (to enter the cave means to return to the Mother Earth's womb) [7, p. 386].

Since at the present stage of science development there is a general convergence between philosophical and literary discourses, science has the occasion to turn to this phenomenon in art. Examples are found in the discursive experience of such significant figures of the twentieth century as Umberto Eco and Jürgen Habermas, in whose works the mutual influence of the literary and philosophical components acquires further development on a qualitatively new level. In particular, philosophers, 
artists and writers turned to the myth (image/symbol) of the Cave at different times. Among others was Iris Murdoch as well. In her fiction, the writer actively used various paradigms of culturology, in particular the Cave paradigm.

This problem was previously investigated mainly in epistemological G. Anikin (1971), I. Mizinina (1991), S. Pavlychko (1993), gender D. Johnson (1987) and chronotopic O. Aliseienko (2001) aspects. However, the ethical and aesthetic aspects were not adequately covered: the literary form as such, its artistic structure remained out of focus. Therefore, the purpose of the article is to study the specifics of the Cave paradigm embodiment in the genrelogical structure of philosophical novel. Investigation of this paradigm in such view will make it possible to realize the resources of the author's style, emphasizing the connection between the author's ethics and the aesthetics of her artistic embodiment.

An example of an indirect biblical interpretation of the cave paradigm (hell / paradise) in Iris Murdoch's novel "The Sea, the Sea" (1978) can be an episode in which the explicit author of the novel (theatre director) Charles Arrowby, while writing his memoirs, compares his own reflections with wandering in the dark cave, where the light falls only through different holes. Among these spots of light is the largest one, to which he is half-consciously approaching, although it is unknown what it may be for him: the "window" behind which the day shines (heaven), or the slot from which the flame breaks out of the center of the earth (hell) [1, p. 79]. With this episode, the writer tries to bring the traditional Christian outlook closer to the world-view of her most beloved philosopher - Plato. In this case the proto-text is the famous Plato's myth about the Cave (Republic; 514). Prisoners in the cave are at first chained with their backs to the center, they are hung by the wall so that they can only see the imitation of the objects - the shadows on the wall (their own and other objects). Later, they are helped to remove the chains; they turn round and see the fire and objects that cast the shadows. Later still they escape from the cave, they see the outside world in the sunlight, and eventually see the sun itself [4, p. 114-117].

The meta-text to reveal Murdoch's reception of this myth (parable, by the writer's definition) and interpretations in her novels are her writings: "The Sovereignty of Good over other Concepts" [16, p. 376], 
"The Fire and the Sun: Why Plato Banished the Artists" [13, p. 389], "Concepts of Unity. Art" [11, p. 10].

This parable, according to Murdoch, "portrays a spiritual pilgrimage from appearance to reality" [11, p. 10]. At each stage, when we turn round, get up, raise our heads, we first see the shadows of what is more real and true. In this context, Plato's 'Theory of Forms' symbolizes certain logical and moral issues: "mystical, postulated Forms (or Ideas) are models, archetypes: universals, general concepts as distinct from particular entities, and, in their ethical role, moral ideals active in our lives, radiant icons, images of virtue" [11, p. 10]. The "moral Forms", from Murdoch's point of view, are interrelated. That is why the "Form of Good", pictured in the Cave myth as the sun, to her means the "supreme power" that unifies the rest. As for cognition, Plato regarded the idea of Good has a limit, and it is vaguely recognizable, but having recognized it, we come to the conclusion that it is precisely the cause of all that is the true and beautiful. In the realm of the visible, it gives rise to light and its master, and in the realm of speculation, it is the master, on which the truth and cognition depend [4, p. 117].

The sun as the image of Good in the Cave myth is invisible to people, hence the true understanding of Good in Murdoch's interpretation is hidden, incomprehensible to a person who does not want to accept it. And only one who seeks true light is able to escape the captivity of illusions and selfishness [16, p. 376]. The sun represents the "Form of the Good"; in its light the truth is seen and "it reveals the world, hitherto invisible, and it is also a source of life" [13, p. 389]. Let's compare what Plato thinks about this:

It would be correct to consider light and vision to be sun-like, but it would be wrong to admit them to be the Sun itself, and here: it is right to believe that cognition and truth contain the image of the Good, but to consider acknowledge any of them as the Good would be wrong: the Good due to its properties needs to be appreciated even more [4, p. 114].

By the way, the metaphor of the Cave, according to S. Pavlychko, consists of such factors as vision and look. The researcher, in particular, emphasized that in Murdoch's novels "vision is a technique, and it often focuses on an art object" [3, p. 32]. That's why Murdoch in her essays supports Plato's criticism of art, since art (she emphasizes - mediocre 
art) "substitutes reality by manifestations, distracts from reality" [3, p. 33], and only "good art," which embodies the ideas of the highest moral category - the Good, is true, it inspires, gives a creative impulse to its perceivers.

Developing the metaphor of the sun, as the understanding of the Good, Murdoch finds it extremely rich: the sun is real, but too distant. "It gives light and energy and enables us to know the truth. In its light, we see the things of the world in their true relationships. Looking at it itself is supremely difficult and is unlike looking at things in its light" [16, p. 376].

So, we see the difference: we know the Good is still somewhere beyond our self, which is rather a "place of illusion". That is why, the maxim "the Good is a transcendent reality," in the writer's understanding, is inseparable from virtue as "an attempt to pierce the veil of selfish consciousness and join the world as it really is" [16, p. 376-377]. However, here Murdoch warns that in this attempt, as "the empirical fact about human nature", there is no guarantee of complete success, so the Cave is more likely a "magic space".

This discrepancy between the "magic space" and the real one is the negative moment, which, as S. Pavlychko rightly pointed out, also concerns Murdoch's own fiction:

Murdoch's intellectualism, shown in the desire to grasp certain speculative ideas, first of all moral ones, captured her so much that she was blinded by them, like those prisoners who came out of the cave in her favourite platonic parable. She saw the sun, that is, she attained her main idea and achieved the purpose of her creativity, but, blinded by its bright rays, released from her view contours of the real world [3, p. 38].

Apropos, O. Spengler also spoke of the cave as a "magical space":

The idea of the Logos, in the broadest sense, as extracted from the magical light of the Cave, is the exact parallel of this feeling in magical thinking. It means that from the inaccessible Deity his spirit, his Word as a carrier of light and the bestowal of Good, comes into contact with the essence of man, to magnify, to fill, to redeem him [5, p. 40].

There are other aspects. For example, Deborah Johnson (supporter of feminist criticism) explores Murdoch's novels (and the cave image in 
particular), mainly in the gender aspect [10], referring to the works of L. Irigaray [9] and S. Gilbert, S. Gubar [8]. According to L. Irigaray, the specific images of the cave as theatre space (enceinte théâtrale) transfer the gender difference (male-female) in a series of hierarchically organized oppositions (a woman becomes a shadow of a man or his mirror image) [10, p. 92].

In general, representatives of feminist criticism actively use the idea of Sigmund Freud about the cave as a 'woman's place', the closed space of the female's womb, mysterious and often sacred [6, p. 379]. In particular, for L. Irigaray the Cave of Plato is the metaphor of male representation of the womb. The image of the Cave here combines a number of oppositions, the differences between external and internal, sublime and foul, daylight and light of the fire, escapee and prisoner, truth and shadow, reality and imagination, speculative and sensual, good and evil and so on.

These oppositions to Irigaray signify ascension. In this context, the meaning of the 'woman's place' (cave) is devaluated by a single principle - divine parental logos depicted in the myth in the form of the sun $[9$, p. 306]. The sun dazzles the one who comes out of the cave, and he is not able to see anything, however, returning to the cave, he also sees nothing in the dark. As well as L. Irigaray, S. Gilbert and S. Gubar were interested how a woman-writer with her imaginative thinking reconciles the metaphorically-negative potential of the cave with its positive mystical possibilities; how she can distinguish her creative essence from the unreal shadows of her own imagination [8, p. 95].

Unlike her theoretical and philosophical writings, in her novels Murdoch ironically plays with the Plato's myth. In several Murdoch's novels the Cave is perceived rather as a "place of initiation" (D. Johnson) $[10$, p. 92] of the young characters, who enter it, such as the dangerous climb of Tom McCaffrey to the source Lud's Rill under the Spa-resort that he imagined in the form of a grotto ("The Philosopher's Pupil") [15, p. 520-523]; the deadly peril of Peirce who, because of unrequited love, decides to stay during the tide at Gunnar's Cave ("The Nice and the Good") [14, p. 227-228]; Dora experiences a sense of identifying herself with a mystical bell that appears in her reception as an "inhabited cave" ("The Bell") [12, p. 267]. But in the novel "The Sea, the Sea" the Cave is both the confined theater space ("theatrical enclosure") in which we live 
and "the place of contemplation, of confrontation with inner truth, a testing-place" [10, p. 91].

By the recognition of the narrator - theatre director Charles Arrowby - every kind of art distorts life, replaces it, and most of all the theatre [1, p. 164]. The topos of the theatre in the novel is the home of illusions; it is not a real space. For the protagonist it is that "temple of insincerity", which he leaves to restore "true feelings". However, this is another illusion. Here Murdoch rather supports the view of Charles's cousin - James, who is convinced that people cannot get rid of illusions, because man is a creature incomprehensible, directed towards his self. $\mathrm{He}$ assures Charles that direction inside is in people the most impressive, even more impressive than our consciousness. But we can not just enter the cave and see. Almost everything that we think, we know about our consciousness is not thorough knowledge. People themselves are fakes, falsifications, and total illusions [1, p. 174].

This author's interpretation actually illustrates the theory of K. G. Jung [7, p. 386], who believed that the Cave also embodied the mystery, the inaccessibility of the unconscious, the motive of overcoming the internal forces.

The sun in the "mystical" cave of Charles Arrowby is his imaginary beloved Hartley. For Charles all other women, in comparison with her, are only pale images, shadows [1, p. 80]. That is why the Plato's allegory of the Cave is perceived here as the metaphor of the human aptitude to eikasia, the inability to perceive reality, and it is compared by D. Johnson with Sibyl's Cave as an image of illusion [10, p. 87] as well as with Prospero's cell, where one can find out the truth and where the illusion of power (the illusion of the theater) finally begin to disappear [10, p. 90-91]. This happens when Charles decides to live a lonely life; his remote house on the seashore, he also calls his cave $[1, \mathrm{p} .6]$.

Another but no less important interpretation of the Plato's myth, both in the context of this novel and the complete oeuvre of the writer, is the moment of death. In James's perception, for example, death is likened to a bright flash of light (dazzling at the exit of the cave), when a person is given the opportunity to see the reality as a whole, first only as a bright flash - something horrible, dazzling, immense. But if you are able to comprehend and keep it, then you are free [1, p. 369]. Hence, life is the illusion and death is the release from illusions. In this way, not only the 
character, but also the real author, believes that man becomes devoid of his preferences, passions, desires, everything that binds him to the world of illusions - is freed from the Wheel (another polyvalent symbol of the writer).

Hereby, Murdoch articulating her own ideas by the words of her character again proves that metaphors and symbols, although very convenient for posing philosophical questions, are not capable of explaining the truth, "the truth is hidden deeper" [1, p. 370].

Consequently, in the broad sense, S. Pavlychko and I. Mizinina rightly regard the metaphor of the Cave in Murdoch's fiction as a reflection of human cognition ("the process of acquiring knowledge") [2, p. 7], "the human path to awareness, to the truth" [3, p. 31]), which is also confirmed by the writer herself: "the higher reality is studied first in the form of shadows and images" [13, p. 389].

However, to consider it only as a reflection of the "process of awareness" is not enough to grasp the essence of the problem. After all, the paradigm always fits into the context of modern culture; it is actualized by this culture and usually requires a description (aesthetic aspect).

Iris Murdoch, as a representative of classical culture, manifests the potency of the Cave paradigm in classical patterns. In her novels there are almost all modern themes (social, philosophical, psychological, sexual, etc.) but their aesthetic embodiment remains extremely correct. The author's interpretation of the Cave paradigm is unique, worthy of a true philosopher: this is no longer a real topos, but the consciousness of her characters as such, with all its mazes, shadows, dark corners, unconscious queer illusions.

That is, the Cave in Murdoch's fiction is not so much a Form but Content. In this way, Iris Murdoch appeals to the moral aspect of the human nature, with the development of which she relates the possibility of harmonious relations with the world. In such a compromise she hopes for reconciliation of moral values with the truth of real life. Consequently, the meaning of this paradigm is disclosed in correlation of the incompatible things: the material (topos) and the spiritual (logos) factors.

Full of polyvalent symbols and metaphors the multi-level structure of Iris Murdoch's philosophical novels does not provide an unequivocal 
interpretation; it is perceived as a phenomenological fact, permeated with intertextual links that extend beyond her fiction texts. The infinite semantic perspective of symbolic images, paradigms created by the writer is comprehended only through communication and is designed for the active reaction of the reader, so that the symbolic (mythological) form potentially acquires its meaning (both new and different one) in the perceiver's consciousness.

1. Мердок А. Море, море / А. Мердок ; [пер. с англ. М. Лорие]. - Киев : БМП Борисфен, 1995. - 480 с.

2. Мизинина И. Н. Романы А. Мердок конца 1960-х - начала 1970-х гг. (идеи философии Платона в зеркале художественной структуры) : автореф. дис. на соискание ученой степени канд. филол наук : спец. 10.01.05 „Литература стран Западной Европы, Америки и Австралии” / И. Н. Мизинина. - Москва, 1991. - 16 с.

3. Павличко С. Д. Лабіринти мислення. Інтелектуальний роман сучасної Великобританії / С. Д. Павличко. - Київ : Наук. думка, 1993. - 104 с.

4. Платон. Государство // Хрестоматия по западной философии: Античность. Средние века. Возрождение / авт.-сост. Л. И. Яковлева и др. - Москва : ООО „Изд-во Астрель”; ООО „Изд-во АСТ”, 2003. C. $101-122$.

5. Самосознание европейской культуры XX века: Мыслители и писатели Запада о месте культуры в современном обществе. - Москва : Политиздат, 1991. - 366 с.

6. Фрейд 3. Толкование сновидений / 3. Фрейд. - Киев : Здоровье, 1991. $384 \mathrm{c}$.

7. Энциклопедия. Символы, знаки, эмблемы / авт.-сост. В. Андреева и др. Москва : ООО „Изд-во Астрель”: ООО „Изд-во АСТ”, 2004. - 556 с.

8. Gilbert S. The Madwoman in the Attic: The Woman Writer and the Nineteenth-Century Literary Imagination / Sandra Gilbert, Susan Gubar. New Haven and London : Yale University Press, 1979. - 719 p.

9. Irigaray L. Speculum de l'autre femme / Luce Irigaray. - Paris : Minuit, 1974. -464 p.

10. Johnson D. Key Women Writers: Iris Murdoch / Deborah Johnson. Brighton : The Harvester Press, 1987. - 130 p.

11. Murdoch I. Conceptions of Unity. Art / Iris Murdoch // Murdoch I. Metaphysics as a Guide to Morals. - New York : Penguin Books Ltd., 1993. P. 1-24.

12. Murdoch I. The Bell / Iris Murdoch. - London : Chatto\&Windus, 1959. $316 \mathrm{p}$. 
13. Murdoch I. The Fire and the Sun: Why Plato Banished the Artists / Iris Murdoch // Murdoch I. Existentialists and Mystics. Writings on philosophy and literature. - New York : Penguin Books Ltd., 1999. - P. 386-463.

14. Murdoch I. The Nice and The Good / Iris Murdoch. - London : Chatto\&Windus, 1968. - $362 \mathrm{p}$.

15. Murdoch I. The Philosopher's Pupil / Iris Murdoch. - New York : The Viking Press, 1983. - $576 \mathrm{p}$.

16. Murdoch I. The Sovereignty of Good over other Concepts. The Leslie Stephen Lecture / Iris Murdoch // Murdoch I. Existentialists and Mystics. Writings on philosophy and literature. - New York : Penguin Books Ltd., 1999. - P. 363-385.

\title{
ПОЛИВАЛЕНТНОСТЬ ПАРАДИГМЫ ПЕЩЕРЫ: РЕЦЕПЦИЯ АЙРИС МЕРДОК
}

\author{
Алена Анатольевна Матийчак \\ orcid.org/0000-0002-8190-0427 \\ amatiychak@gmail.com
}

Кандидат филологических наук, доцент

Кафедра иностранных языков для гуманитарных факультетов

Черновицкий национальный университет имени Юрия Федьковича

Ул. Коиюбинского, 2, 58012, г. Черновиь, Украина

Аннотация. Рассмотрена художественно-философская парадигма пещеры в контексте творчества английской писательницы-философа Айрис Мердок. Предмет исследования - ее художественные и философские тексты. Целью статьи является изучение специфики воплощения парадигмы Пещеры в аспекте жанровой структуры философского романа Мердок. Исследование этой парадигмы в таком ракурсе позволяет проанализировать ресурсы авторского стиля, в частности связь между авторской этикой и эстетикой ее произведений. В данном случае прототекстом выступает знаменитый миф Платона о Пещере, и метатекстом для выявления рецепции Мердок этого мифа и его интерпретаций в ее романах служат собственные философские работы писательницы: „Верховенство Добра над другими понятиями”, „Огонь и солнце: почему Платон изгнал художников”, „Концепции единства. Искусство”. Предложен многоаспектный подход к решению поставленной проблемы, в котором, наряду с гносеологическим и гендерным аспектами, особое внимание уделяется этико-эстетическому компоненту структуры художественных текстов Мердок. Разворачивая метафору солнца как понимание Добра, Мердок считает ее чрезвычайно богатой: солнце является реальным, но слишком отдаленным; оно дает свет и энергию, а также возможность познать истину. В отличие от теоретических и философских 
произведений, в своих романах Мердок иронично играет с мифом Платона. Она считает Пещеру „магическим пространством”, „театральным пространством”, „сакральным пространством”, „местом инициации” или „местом иллюзий”. Пещера в произведениях Айрис Мердок является не столько „формой”, сколько „содержанием”. Авторская интерпретация парадигмы Пещеры уникальна, достойна настоящего философа; она проявляется с помощью корреляции материального (топос) и духовного (логос) факторов: это уже не реальный топос, а сознание ее персонажей, со всеми запутанными лабиринтами, тенями, темными углами, неосознанными иллюзиями.

Ключевые слова: Айрис Мердок, рецепция, парадигма Пещеры, Добро как моральная категория, гносеологический, гендерный, этико-эстетический аспекты.

\title{
ПОЛІВАЛЕНТНІСТЬ ПАРАДИГМИ ПЕЧЕРИ: РЕЦЕПЦІЯ АЙРІС МЕРДОК
}

\author{
Альона Анатоліївна Матійчак \\ orcid.org/0000-0002-8190-0427 \\ amatiychak@gmail.com \\ Кандидат філологічних наук, доиент \\ Кафедра іноземних мов для гуманітарних факультетів \\ Чернівецький наиіональний університет імені Юрія Федьковича \\ Вул. Коиюбинського, 2, 58012, м. Чернівиі, Україна
}

Анотація. Висвітлено художньо-філософську парадигму печери в контексті творчості англійської письменниці і філософа Айріс Мердок. Предметом дослідження постають ऑї художні та філософські тексти. Метою статті $\epsilon$ вивчення специфіки втілення парадигми Печери в аспекті жанрової структури філософського роману Мердок. Дослідження цієї парадигми в такому ракурсі дозволяє проаналізувати ресурси авторського стилю, зокрема зв'язок між авторською етикою та естетикою іiі художніх творів. В даному випадку прототекстом виступає славнозвісний міф Платона про печеру, метатекстом для виявлення рецепції Мердок щодо цього міфу та його інтерпретацій в ії романах слугують праці письменниці: „Верховенство Добра над іншими поняттями”, „Вогонь і сонце: чому Платон вигнав митців”, „Концепції Єдності. Мистецтво”. Запропоновано багатоаспектний підхід до розв'язання означеної проблеми. Крім гносеологічного та гендерного аспектів, значна увага приділена етико-естетичному компоненту структури художніх текстів Мердок. Розгортаючи метафору сонця як розуміння Добра, Мердок вважає iï надзвичайно багатою: сонце реальне, але надто віддалене; воно дає світло й енергію, а також змогу пізнати істину. На відміну від іiі 
теоретичних і філософських творів, у своїх романах Мердок іронічно грає 3 міфом Платона. Вона вважає Печеру „магічним простором”, „театральним простором”, „сакральним простором”, „місцем ініціації” або ж „місцем ілюзій”. Звідси, печера є не стільки „формою”, скільки „змістом”. Авторська інтерпретація парадигми печери унікальна, гідна справжнього філософа; вона виявляється за допомогою кореляції матеріального (топос) та духовного (логос) чинників: це вже не справжній топос, а свідомість її персонажів як така, 3 усіма іiі лабіринтами, тінями, темними кутами, неусвідомленими ілюзіями.

Ключові слова: Айріс Мердок, рецепція, парадигма печери, Добро як моральна категорія, гносеологічний, гендерний, етично-естетичний аспекти.

\section{References}

1. Murdoch I. More, more [The Sea, the Sea]. Kyiv, 1995, 480 p. (in Russian).

2. Mizinina I. N. Romany I. Murdoch kontsa 1960-kh - nachala 1970-kh gg. (Idei filosofii Platona $v$ zerkale khudozhestvennoy struktury) [I. Murdoch's novels of the late 1960s - early 1970s. (ideas of Plato's philosophy in the mirror of the artistic structure)]. Extended abstract of $\mathrm{PhD}$ dissertation. Moscow, 1991, 16 p. (in Russian).

3. Pavlychko S. D. Labirynty myslennya. Intelektual'nyy roman suchasnoyi Velykobrytanyy [Labyrinths of thinking. Intellectual novel of modern UK]. Kyiv, 1993, 104 p. (in Ukrainian).

4. Plato. Gosudarstvo [State]. In: Readings on Western Philosophy: Antiquity. Middle Ages. Renaissance. Moscow, 2003, pp. 101-122. (in Russian).

5. Samosoznaniye yevropeyskoy kul'tury XX veka: Mysliteli i pisateli Zapada o meste kul'tury v sovremennom obshchestve [Self-consciousness of European culture of the twentieth century: Thinkers and writers of the West about culture in modern society]. Moscow, 1991, 366 p. (in Russian).

6. Freud S. Tolkovaniye snovideniy [The Interpretation of Dreams]. Kyiv, 1991, 384 p. (in Russian).

7. Entsiklopediya. Simvoly, znaki, emblemy [Encyclopedia. Symbols, signs, emblems]. Moscow, 2004, 556 p. (in Russian).

8. Gilbert S., Gubar S. The Madwoman in the Attic: The Woman Writer and the Nineteenth-Century Literary Imagination. New Haven and London, 1979, $719 \mathrm{p}$.

9. Irigaray L. Speculum de l'autre femme. Paris, 1974, 464 p.

10. Johnson D. Key Women Writers: Iris Murdoch. Brighton, 1987, 130 p.

11. Murdoch I. Conceptions of Unity. Art. In: Murdoch I. Metaphysics as a Guide to Morals. New York, 1993, pp. 1-24.

12. Murdoch I. The Bell. London, 1959, 316 p. 
13. Murdoch I. The Fire and the Sun: Why Plato Banished the Artists. In: Murdoch I. Existentialists and Mystics. Writings on philosophy and literature. New York, 1999, pp. 386-463.

14. Murdoch I. The Nice and The Good. London, 1968, 362 p.

15. Murdoch I. The Philosopher's Pupil. New York, 1983, 576 p.

16. Murdoch I. The Sovereignty of Good over other Concepts. The Leslie Stephen Lecture. In: Murdoch I. Existentialists and Mystics. Writings on philosophy and literature. New York, 1999, pp. 363-385.

\section{Suggested citation}

Matiychak A. Polyvalence of the Cave Paradigm: Iris Murdoch's Reception. Pytannia literaturoznavstva, 2018 , pp. 317-329. doi: $10.31861 /$ pytlit2018.98.317

Стаття надійшла до редакції 28.10.2018 p. Стаття прийнята до друку 4.12.2018 р. 